\title{
Meta-analysis of nutrient budgets in organic farms across Europe
}

\author{
Marie Reimer (D) - Kurt Möller (iD) \\ Tobias Edward Hartmann (D)
}

Received: 15 April 2020 / Accepted: 23 April 2020 /Published online: 26May 2020

(C) The Author(s) 2020

\begin{abstract}
Nutrient supply to organic farms is a highly discussed topic in Europe, due to the restricted availability of external fertilizer resources and the use of contentious inputs. To optimize the flow of nutrients throughout the organic farming system, it is firstly necessary to obtain valid data on the nutrient status of organic farms. Nutrient budgets are a valid tool to investigate the nutrient demand or surplus of a system. However, there is currently no comprehensive overview of nutrient budgets of European organic farms. We therefore carried out a meta-analysis on 56 individual studies that reported either farm-gate or soil surface budgets. The analysis showed an imbalance between nutrients, a general surplus of nitrogen $\left(45 \mathrm{~kg} \mathrm{~N} \mathrm{ha}^{-1}\right.$ year $^{-1}$ [95\% confidence interval (CI) 30,61]), magnesium (16 kg Mg ha year $^{-1}$ $[-9,40])$ and sulfur $\left(45 \mathrm{~kg} \mathrm{~S} h a^{-1}\right.$ year $\left.^{-1}[-29,118]\right)$, a balanced phosphorus budget $\left(0 \mathrm{~kg} \mathrm{P} \mathrm{ha}{ }^{-1}\right.$ year $^{-1}[-2$, 2]), and a deficit for potassium (-12 $\mathrm{kg} \mathrm{K} \mathrm{ha}^{-1}$ year $^{-1}[-$ $21,-3])$. We observed large differences between farms
\end{abstract}

Electronic supplementary material The online version of this article (https://doi.org/10.1007/s13165-020-00300-8) contains supplementary material, which is available to authorized users.

M. Reimer $(\bowtie) \cdot$ K. Möller $\cdot$ T. E. Hartmann

Institute of Crop Science, Fertilization and Soil Matter Dynamics (340i), University of Hohenheim, Fruwirthstr 20, 70593 Stuttgart, Germany

e-mail: marie.reimer@uni-hohenheim.de

K. Möller

Center for Agricultural Technology Augustenberg (LTZ), Institute of Applied Crop Science, Kutschenweg 20,

76287 Rheinstetten-Forchheim, Germany that could be partly explained by farm type and budgeting method. Arable and mixed farms showed lower nitrogen, phosphor, magnesium, and sulfur budgets than dairy/beef farms or even vegetable farms, while all farm types besides dairy/beef farms showed deficits for $\mathrm{K}$ budgets. Further, farm-gate budget studies yielded higher budgets than soil surface budgets. Variations between studied countries could also be detected, but the coverage and comparability are low due to differences in studied farm types and budgeting method.

Keywords Nutrient balance $\cdot$ Farm-gate $\cdot$ Metaanalysis $\cdot$ Soil surface $\cdot$ Organic farming $\cdot$ Europe $\cdot$ Farm type

\section{Introduction}

Nutrient management systems of conventional and organic farming differ from each other significantly. While conventional nutrient management relies strongly on external mineral fertilizer inputs, the principal of nutrient management in organic farming is based on biological nitrogen fixation (BNF), nutrient cycling within the farm, and nutrient recycling from urban and other waste streams (Watson et al. 2002a; IFOAM 2017). The use of external fertilizer inputs in the organic farming sector is being controversially discussed. The goal is to limit the amount of contentious inputs such as fertilizers derived from conventional agriculture, like conventional manure (Oelofse et al. 2013), and finite resources like rock phosphate. However, any farm 
export of nutrients like phosphorus $(\mathrm{P})$, potassium $(\mathrm{K})$, magnesium (Mg), and sulfur (S) through sold products should be replenished on the long-term perspective in order to ensure sustainable nutrient management. The goal of sustainable nutrient management should be therefore to have a balance between inputs and outputs, since on the one hand, there is a risk of environmental pollution, e.g., through losses of nutrients via leaching or runoff, when inputs outweigh the outputs (BlicherMathiesen et al. 2014). On the other hand, there is the risk of soil nutrient depletion and loss of soil fertility (Løes and Øgaard 2001; Cooper et al. 2018), when the opposite is the case. Specific studies provided some indication for nutrient imbalances (Berry et al. 2002; Zikeli et al. 2017; Cooper et al. 2018), and that farm type represents an important factor responsible for the variation between farms (Watson et al. 2002a; Ohm et al. 2017). Thereby, stockless arable farms are expected to have lower surpluses of nutrients than stocked farms. Giustini et al. (2008) and Foissy et al. (2013) found a strong relation between stocking density and nitrogen (N) budgets. Vegetable farms are more prone to high nutrient surpluses due to high fertilizer inputs, imbalances between nutrients, and the need for high yields and economic returns due to high production costs (Zikeli et al. 2017). However, there is a lack of studies providing an overview about the situation across the entire organic sector in Europe.

Nutrient budget studies are a valid tool to evaluate the nutrient management strategy of a farm and to quantify potential nutrient oversupplies or demands in agricultural systems (Watson et al. 2002b). Nutrient budget calculations quantify each nutrient input and output of a farming system. Watson et al. (2002b) describe three different methods of budget calculations: farm-gate, soil surface, and system budgets. These methods differ mainly in the boundaries that are drawn to define the agricultural system being investigated. Farm-gate budgets consider the whole farm, while soil surface budgets, also called field budgets, only take into account inputs and outputs to one or more fields. System budgets consider the whole production sector of the agricultural system. These types of budgets are more aggregated and go beyond the farm level and they will not be considered for the present study.

This study aims to provide a comprehensive overview of nutrient budgets of different organic farm types across Europe, by combining and meta-analyzing the results of previously published literature. In this study, the soil surface and farm-gate nutrient budgets of $\mathrm{N}, \mathrm{P}$, $\mathrm{K}, \mathrm{Mg}$, and $\mathrm{S}$ will be examined with regard to the farming type (vegetable, cattle/dairy, mixed or arable farms) and investigated countries in Europe.

\section{Materials and methods}

A survey of CAB-listed literature, published between 1990 and 2019, was conducted to identify papers that report nutrient budget studies of organic farms in Europe. The following search terms were used in various combinations: farm-gate/farm/nutrient; budget/balance/ flows; organic/bio-dynamic/ecological, and Europe. The search resulted in 1827 identified studies. The data from these studies was subsequently scrutinized according to criteria of thematic fit, language requirements (English or German), and availability of descriptive or statistical effects. A study was seen as thematically fitting if it met the following criteria: (1) must have quantified nutrient budgets of $\mathrm{N}, \mathrm{P}, \mathrm{K}, \mathrm{Mg}$, and/or $\mathrm{S}$, (2) the nutrient budgets must be from organically managed farms, fields, or experimental stations, (3) only arable, dairy/beef, mixed (all types of animals), and vegetable farms were considered, and (4) the farms must be located in the geographical region of Europe. Further, only original studies were included; review articles were not taken into account. Additional papers were found by searching the reference lists of already selected papers and by recommendations of experts. Additionally, two unpublished studies were included. Where data for means and standard deviations were missing but ranges were given, estimations after Walter and Yao (2007) and Weir et al. (2018) were used.

Meta-analyses for each nutrient were performed on the whole data set and subsets of data based on farm type (arable, dairy/cattle, mixed, or vegetable farms), method used for nutrient budget analysis (soil surface, or farm-gate budgets), or country of origin, using the metaphor package in $R$ (R Core Team 2018) as described by Viechtbauer (2010). The $\tau^{2}$ parameter was used as a measure of heterogeneity within the dataset. Moderator tests were carried out for the categorical moderator farm type, and budget method separately as well as together with a dummy variable. The $R^{2}$ parameter was used to determine the amount of heterogeneity the moderator variables accounted for. An omnibus test was performed to determine if moderators had a 
significant influence on the nutrient budgets (alpha level 0.05 for the QM test; Viechtbauer 2010).

\section{Results}

The literature search resulted in 56 studies from 15 different countries that met the selection criteria (Table 1). Many studies were discarded since they were not available in English or German but were published in the native language of the origin country. Many studies also investigated only one, two, or three nutrients, mostly $\mathrm{N}, \mathrm{P}$, and $\mathrm{K}$, and not all of the nutrients considered for this meta-analysis (Table 1). This resulted in a very variable study and farm count across the different nutrients. Most studies and farms were examined for $\mathrm{N}$ ( 44 studies/ 621 farms), followed closely by $\mathrm{P}$ (36 studies/556 farms) and K (32 studies/520 farms). However, only six studies (78 farms) were found for $\mathrm{Mg}$ and only three (43 farms) for S. Therefore, a detailed meta-analysis with subsetting for farm types and budget method or a moderator analysis were not performed for these two nutrients. Two studies, Zikeli et al. (2017) and Reimer et al. (under review), considered all five different nutrients at the same (Table 1).

The results of the meta-analysis indicated a surplus of $45 \mathrm{~kg} \mathrm{~N} \mathrm{ha}^{-1}$ year $^{-1}$ [95\% confidence interval (CI) 30 to $61 \mathrm{~kg} \mathrm{~N} \mathrm{ha}^{-1}$ year $^{-1}$ ] over 44 studies and a total of 621 investigated farms if not differentiated among farm types or budget method (Fig. 1, Supplementary Table 1). The meta-analysis for $P$ resulted in a balanced budget of $0 \mathrm{~kg} \mathrm{P} \mathrm{ha}{ }^{-1}$ year $^{-1}$ [95\% CI -2 to $2 \mathrm{~kg} \mathrm{P} \mathrm{ha}^{-1}$ year $^{-1}$ ] over 36 studies and 556 investigated farms. Yet for $\mathrm{K}$, there was an overall deficit of $12 \mathrm{~kg} \mathrm{~K} \mathrm{ha}{ }^{-1}$ year $^{-1}\left[\begin{array}{l}95 \% \\ \mathrm{CI}\end{array}-21\right.$ to $-3 \mathrm{~kg} \mathrm{~K} \mathrm{ha}^{-1}$ year $^{-1}$ ] over 32 studies and 520 investigated farms. For both $\mathrm{Mg}$ and $\mathrm{S}$, there were surpluses of $16 \mathrm{~kg} \mathrm{Mg} \mathrm{ha}{ }^{-1} \mathrm{year}^{-1}\left[\begin{array}{llll}95 \% & \mathrm{CI} & -9 & \text { to }\end{array}\right.$ $40 \mathrm{~kg} \mathrm{Mg} \mathrm{ha}^{-1}$ year $\left.^{-1}\right]$ and $45 \mathrm{~kg} \mathrm{~S}^{-1}$ year $^{-1}$ [95\% $\mathrm{CI}-29$ to $118 \mathrm{~kg} \mathrm{~S}^{-1}$ year $^{-1}$ ] over 6 or 3 studies and 78 or 43 investigated farms, respectively. However, the results for $\mathrm{Mg}$ and $\mathrm{S}$ do not reflect the whole organic sector due to the low study and farm count and therefore, the different studies should be regarded separately.

For Mg, two studies by Bengtsson et al. (2003) and Zikeli et al. (2017) have noticeably higher surpluses than the other four studies. These two studies investigated a dairy farm or vegetable farms, while the lower budget values were found for arable or mixed farms.
Similarly, for S, Zikeli et al. (2017) found very high surpluses (119 kg S ha ${ }^{-1}$ year $^{-1}$ ) on vegetable greenhouse farms while the other two studies found lower surpluses on arable or dairy farms.

There was a high level of heterogeneity for the metaanalysis of $\mathrm{N}, \mathrm{P}$, and $\mathrm{K}$ budgets as well $\left(\tau^{2}\right.$ in Supplementary Table 2). In order to explain parts of the heterogeneity found for the $\mathrm{N}, \mathrm{P}$, and $\mathrm{K}$ budgets, the farm type and budgeting method, as well as a dummy variable consisting of the farm type and the budget method, were used as moderators in a separate metaanalysis for each subset. Almost all moderator tests were statistically significant, except of the farm type moderator for the $\mathrm{P}$ budgets $(p=0.0527$, Table 2$)$. However, the moderators varied in their ability to explain the heterogeneity of results. For N, the most important moderation was due to differences in farm type, which explained $26 \%$ of the heterogeneity. The data indicated that arable and mixed farms have lower mean surpluses (19 or $18 \mathrm{~kg} \mathrm{~N} \mathrm{ha}^{-1}$ year $^{-1}$ ) than dairy/beef farms (77 kg N ha ${ }^{-1}$ year $^{-1}$ ), while vegetable farms had the highest surpluses $\left(117 \mathrm{~kg} \mathrm{~N}^{-1} \mathrm{year}^{-1}\right.$, Fig. 1 and Supplementary Table 1). The same pattern, even if not as strong $\left(R^{2}=6 \%\right)$, was obtained for $\mathrm{P}$, where the means ranged between $-4 \mathrm{~kg} \mathrm{P} \mathrm{ha}^{-1}$ year $^{-1}$ for arable and $24 \mathrm{~kg} \mathrm{P} \mathrm{ha}^{-1}$ year $^{-1}$ for vegetable farms (Fig. 1 and Supplementary Table 1). The observed pattern was different for the K budget. For arable, mixed farms, as well as vegetable farms, we observed deficits between -44 and $-12 \mathrm{~kg} \mathrm{~K} \mathrm{ha}^{-1}$ year $^{-1}$. Only the data for dairy/beef farms provided a slight surplus of $2 \mathrm{~kg} \mathrm{~K} \mathrm{ha}^{-1}$ year $^{-1}$. In total, farm type explained $14 \%$ of the heterogeneity in $\mathrm{K}$ estimates. The budget calculation method showed also some moderation. For N, P, and K, the farm-gate budgets showed higher means than the soil surface budgets (Fig. 1, Supplementary Table 1). Yet, the moderation varied between nutrients, showing higher numerical differences for $\mathrm{N}$ budgets than for $\mathrm{P}$ and $\mathrm{K}$ budgets and different amounts of explained heterogeneity. The $R^{2}$ for $\mathrm{N}$ was $11 \%$ and therefore less than half of the one attributed to farm type (Table 2). For K, the $R^{2}$ was also slightly lower, while for $\mathrm{P}$, the $R^{2}$ was more than doubled. The strongest moderation, however, was observed when farm type and budget method were combined, except for $\mathrm{N}$ where farm type had a $2 \%$ higher $R^{2}$. For $\mathrm{P}$ and $\mathrm{K}$, both variables together were able to explain about $30 \%$ of the heterogeneity, which is approximately doubled from what one variable could explain on its own. 
Table 1 Overview of studies used in the meta-analysis. $\mathrm{N}$ represents the number of investigated farms per study

\begin{tabular}{|c|c|c|c|c|c|c|c|c|c|}
\hline Study & $\mathrm{N}$ & Farm type & Budget kind & Country & $\mathrm{N}$ & $\mathrm{P}$ & $\mathrm{K}$ & $\mathrm{Mg}$ & $\mathrm{S}$ \\
\hline Goulding et al. (2008) & 1 & Farm-gate & Arable & GBR & -22.6 & -2.6 & -39.2 & & \\
\hline Klem et al. (2007) & 8 & Farm-gate & Arable & DEU & 26.1 & & & & \\
\hline Küstermann et al. (2010) & 1 & Farm-gate & Arable & DEU & 35.7 & & & & \\
\hline Nowak et al. (2013) & 20 & Farm-gate & Arable & FRA & 27.6 & & & & \\
\hline Nowak et al. (2013) & 19 & Farm-gate & Arable & FRA & & 9.9 & 1.8 & & \\
\hline Reimer et al. (in review) & 20 & Farm-gate & Arable & DEU & 18.9 & -2.8 & 4.5 & 7.2 & 12.2 \\
\hline Cuttle (2002) & 1 & Farm-gate & Dairy/beef & GBR & 157.0 & 2.0 & 15.0 & & \\
\hline Eriksen and Askegaard (2000) & 1 & Farm-gate & Dairy/beef & DNK & & & & & 2.6 \\
\hline Fortune et al. (1999) & 3 & Farm-gate & Dairy/beef & GBR & & 7.0 & 21.6 & & \\
\hline Fowler et al. (1993) & 5 & Farm-gate & Dairy/beef & GBR & 9.7 & 3.4 & 14.0 & & \\
\hline Goulding et al. (2000) & 2 & Farm-gate & Dairy/beef & GBR & 70.2 & -2.0 & 5.4 & & \\
\hline Goulding et al. (2008) & 2 & Farm-gate & Dairy/beef & GBR & 30.7 & -12.1 & -39.7 & & \\
\hline Gruber et al. (2001) & 1 & Farm-gate & Dairy/beef & AUT & 4.0 & -3.0 & -34.0 & & \\
\hline Haas et al. (2007) & 26 & Farm-gate & Dairy/beef & DEU & 43.0 & -2.8 & 0.8 & & \\
\hline Halberg et al. (1995) & 14 & Farm-gate & Dairy/beef & DNK & 124.0 & & & & \\
\hline Hege et al. (2003) & 33 & Farm-gate & Dairy/beef & DEU & 47.0 & -4.4 & -18.3 & & \\
\hline Klem et al. (2007) & 8 & Farm-gate & Dairy/beef & DEU & 66.4 & & & & \\
\hline Løes and Øgaard (1997) & 12 & Farm-gate & Dairy/beef & NOR & & 44.0 & 156.2 & & \\
\hline Løes and Øgaard (2001) & 5 & Farm-gate & Dairy/beef & NOR & & 3.8 & & & \\
\hline Nielsen and Kristensen (2005) & 13 & Farm-gate & Dairy/beef & DNK & 106.0 & 6.0 & & & \\
\hline Nowak et al. (2013) & 36 & Farm-gate & Dairy/beef & FRA & 55.5 & & & & \\
\hline Nowak et al. (2013) & 34 & Farm-gate & Dairy/beef & FRA & & 0.0 & -1.9 & & \\
\hline Padel et al. (2013) & 12 & Farm-gate & Dairy/beef & AUT & 101.0 & 0.8 & 8.3 & & \\
\hline Padel et al. (2013) & 5 & Farm-gate & Dairy/beef & BEL & 225.5 & 24.0 & 32.5 & & \\
\hline Padel et al. (2013) & 7 & Farm-gate & Dairy/beef & DNK & 80.3 & -3.0 & 1.5 & & \\
\hline Padel et al. (2013) & 7 & Farm-gate & Dairy/beef & FIN & 118.0 & -2.0 & -6.5 & & \\
\hline Padel et al. (2013) & 17 & Farm-gate & Dairy/beef & GBR & 119.8 & 45.3 & 2.8 & & \\
\hline Padel et al. (2013) & 7 & Farm-gate & Dairy/beef & ITA & 117.0 & 0.8 & 2.5 & & \\
\hline Padel et al. (2013) & 14 & Farm-gate & Dairy/beef & ROU & 80.5 & 4.3 & 9.0 & & \\
\hline Ruane et al. (2013) & 21 & Farm-gate & Dairy/beef & IRL & & 9.4 & & & \\
\hline Starz et al. (2013) & 10 & Farm-gate & Dairy/beef & AUT & 41.9 & 1.8 & 12.1 & & \\
\hline Steinshamn et al. (2004) & 1 & Farm-gate & Dairy/beef & NOR & 40.8 & 0.6 & & & \\
\hline Taube et al. (1997) & 1 & Farm-gate & Dairy/beef & DEU & 110.0 & & & & \\
\hline Watson and Atkinson (1999) & 2 & Farm-gate & Dairy/beef & GBR & 157.5 & & & & \\
\hline Wieser et al. (1996) & 9 & Farm-gate & Dairy/beef & DEU & -7.7 & 0.8 & 4.2 & & \\
\hline Bachinger and Stein-Bachinger (2000) & 2 & Farm-gate & Mixed & $\mathrm{DEU}$ & 16.0 & & & & \\
\hline Gutser et al. (2002) & 9 & Farm-gate & Mixed & DEU & 35.2 & -6.6 & -10.7 & & \\
\hline Hansen et al. (2000) & 6 & Farm-gate & Mixed & DNK & 97.2 & & & & \\
\hline Korsaeth (2012) & 3 & Farm-gate & Mixed & NOR & -21.9 & -9.3 & -9.3 & & \\
\hline Loges et al. (2006) & 2 & Farm-gate & Mixed & DEU & 14.8 & & & & \\
\hline Nesme et al. (2012) & 23 & Farm-gate & Mixed & FRA & & 10.3 & & & \\
\hline Nolte and Werner (1994) & 1 & Farm-gate & Mixed & DEU & 11.0 & -2.9 & -65.0 & -8.4 & \\
\hline Oelofse et al. (unpublished data) & 10 & Farm-gate & Mixed & $\mathrm{CHE}$ & 57.6 & 0.2 & -1.4 & & \\
\hline Oelofse et al. (unpublished data) & 7 & Farm-gate & Mixed & DNK & 35.2 & 12.2 & 24.8 & & \\
\hline
\end{tabular}


Table 1 (continued)

\begin{tabular}{|c|c|c|c|c|c|c|c|c|c|}
\hline Study & $\mathrm{N}$ & Farm type & Budget kind & Country & $\mathrm{N}$ & $\mathrm{P}$ & $\mathrm{K}$ & $\mathrm{Mg}$ & $\mathrm{S}$ \\
\hline Oelofse et al. (unpublished data) & 11 & Farm-gate & Mixed & EST & 24.6 & -2.7 & -2.9 & & \\
\hline Oelofse et al. (unpublished data) & 8 & Farm-gate & Mixed & GBR & 22.9 & -2.9 & -2.2 & & \\
\hline Oelofse et al. (unpublished data) & 10 & Farm-gate & Mixed & HUN & 16.2 & -3.0 & -3.1 & & \\
\hline Oelofse et al. (unpublished data) & 5 & Farm-gate & Mixed & ITA & 35.3 & 10.7 & 6.6 & & \\
\hline Goulding et al. (2000) & 1 & Farm-gate & Vegetable & GBR & 96.0 & 1.9 & -20.0 & & \\
\hline Zikeli et al. (2017) & 22 & Farm-gate & Vegetable & DEU & 196.8 & 48.0 & -143.2 & 70.7 & 119.0 \\
\hline Andrist-Rangel et al. (2007) & 3 & Soil surface & Arable & SWE & & & -44.9 & & \\
\hline Asdal and Bakken (1999) & 29 & Soil surface & Arable & NOR & 30.1 & 7.1 & -72.7 & & \\
\hline Asdal and Bakken (1999) & 30 & Soil surface & Arable & NOR & 21.6 & -5.2 & -60.0 & & \\
\hline Boldrini et al. (2007) & 6 & Soil surface & Arable & ITA & 246.0 & & & & \\
\hline Erhart et al. (2002) & 1 & Soil surface & Arable & AUT & 40.2 & -7.9 & 4.8 & & \\
\hline Fliessbach et al. (2000) & 2 & Soil surface & Arable & CHE & -175.0 & -5.5 & -27.0 & 5.5 & \\
\hline Haraldsen et al. (1999) & 3 & Soil surface & Arable & NOR & 17.3 & -1.0 & -67.3 & & \\
\hline Hartl and Erhart (2002) & 1 & Soil surface & Arable & AUT & 40.3 & -8.0 & 4.7 & & \\
\hline Migliorini et al. (2014) & 2 & Soil surface & Arable & ITA & -10.7 & & & & \\
\hline Möller (2009b) & 8 & Soil surface & Arable & DEU & 58.1 & & & & \\
\hline Morari et al. (2012) & 2 & Soil surface & Arable & ITA & 49.1 & & & & \\
\hline Oehl et al. (2002) & 6 & Soil surface & Arable & CHE & & -6.7 & & & \\
\hline Tagmann et al. (2001) & 2 & Soil surface & Arable & CHE & & 6.7 & & & \\
\hline Thorup-Kristensen et al. (2012) & 3 & Soil surface & Arable & DNK & -31.7 & -12.0 & -56.0 & & \\
\hline Torstensson et al. (2006) & 2 & Soil surface & Arable & SWE & -11.0 & -8.5 & -19.0 & & \\
\hline Bengtsson et al. (2003) & 1 & Soil surface & Dairy/beef & SWE & & -0.5 & -23.5 & 39.3 & \\
\hline Øgaard and Hansen (2010) & 28 & Soil surface & Dairy/beef & NOR & & & -51.5 & & \\
\hline Anglade et al. (2015) & 68 & Soil surface & Mixed & FRA & 38.0 & & & & \\
\hline Askegaard and Eriksen (2000) & 4 & Soil surface & Mixed & DNK & & & 5.3 & & \\
\hline Berry et al. (2003) & 9 & Soil surface & Mixed & GBR & 23.2 & 8.2 & -11.7 & & \\
\hline Foissy et al. (2013) & 28 & Soil surface & Mixed & FRA & -6.0 & -1.4 & -15.0 & & \\
\hline Gutser et al. (2002) & 9 & Soil surface & Mixed & DEU & 7.6 & -7.4 & -16.2 & & \\
\hline HungChun et al. (2016) & 3 & Soil surface & Mixed & DEU & 25.7 & & & & \\
\hline Korsaeth and Eltun (2000) & 2 & Soil surface & Mixed & NOR & -43.6 & & & & \\
\hline Schmidtke et al. (in press) & 32 & Soil surface & Mixed & DEU & -11.0 & -9.0 & -38.9 & 11.8 & \\
\hline Erhart et al. (2002) & 1 & Soil surface & Vegetable & AUT & 70.7 & -12.4 & 27.2 & & \\
\hline
\end{tabular}

The budgets not only differed between farm type and budgeting method, but there were also different amounts of studies and investigated farms for each subset (Fig. 1 and Supplementary Table 1). Most studies use the farmgate method to calculate the budget. Especially for N, the difference between numbers of studies based on farm-gate $(n=30)$ and soil surface $(n=19)$ budgets was high. For K, the amount of investigated farms by farm-gate balances was double as the number of farms analyzed by soil surface studies. The study and farm count also differed among farm types. Most studies examined dairy/beef farms, closely followed by arable farms and mixed farms. Yet, there are noticeably lower amounts of studies done on vegetable farms. Further, the soil surface budget method was mostly used for arable and mixed farms, and almost all dairy/beef farms were examined using the farm-gate budget method.

The literature research yielded studies investigating farms from 15 different countries. The number of studies and farms differed highly. Most studies investigated German farms, followed by studies from Great Britain, Denmark, Norway, and Austria (Fig. 2, Supplementary 

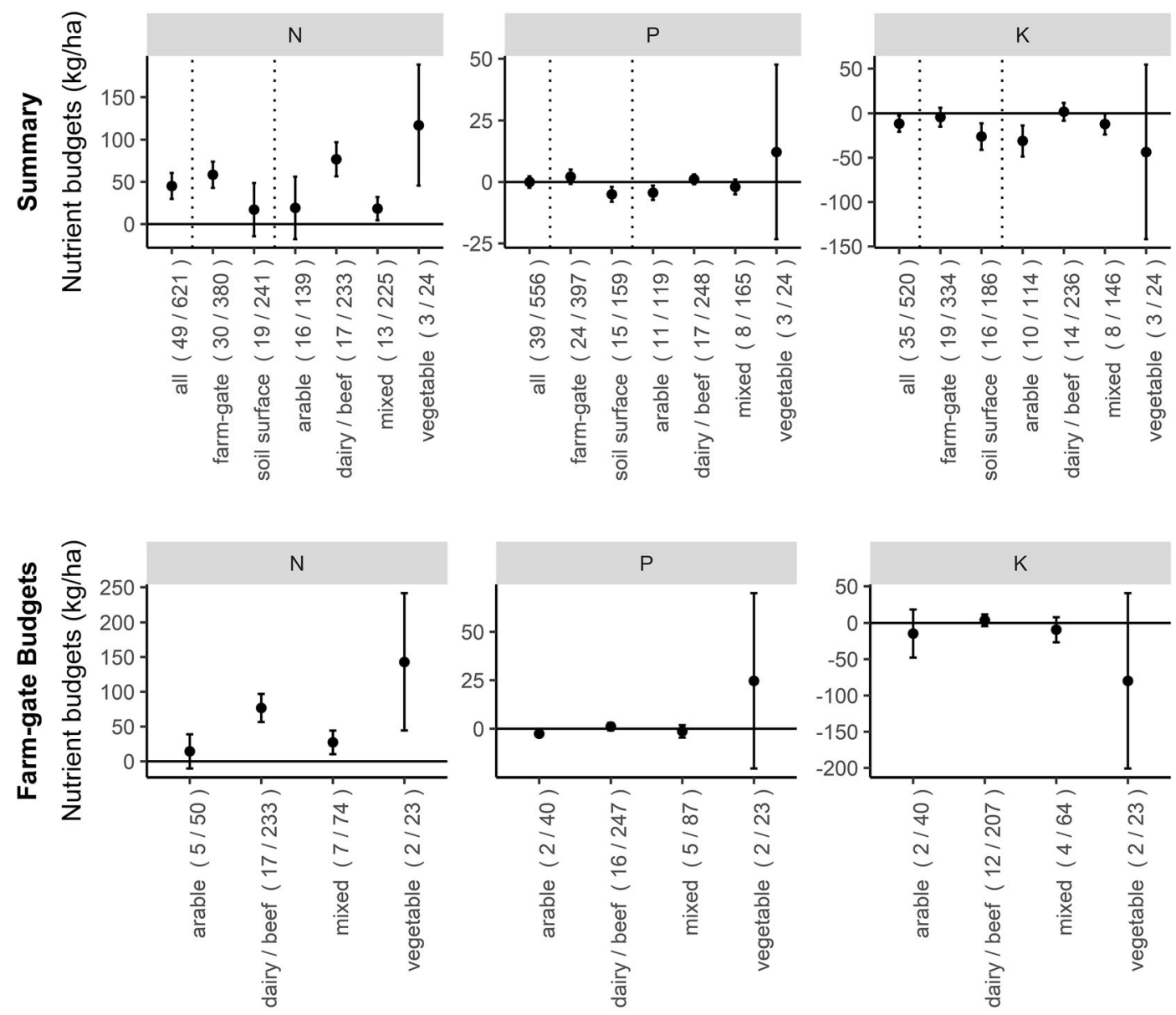

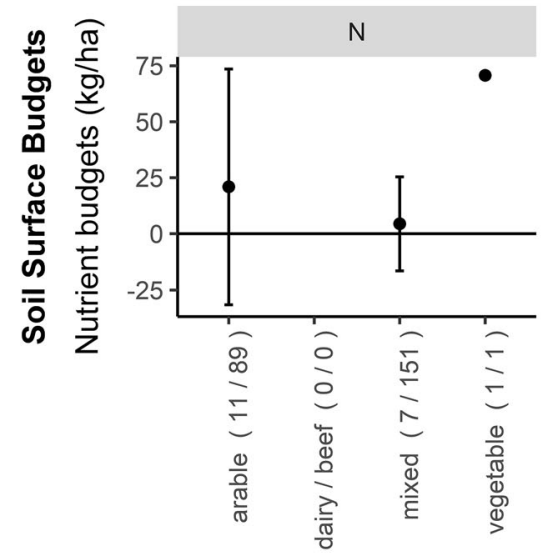

Fig. 1 Summary of the meta-analysis results of N, P, and K budgets as overall averages (top row), farm-gate budgets (middle row), and soil surface studies (bottom row). Dots represent the

Table 1). Although only very few studies have been conducted in France, the number of farms investigated was high.
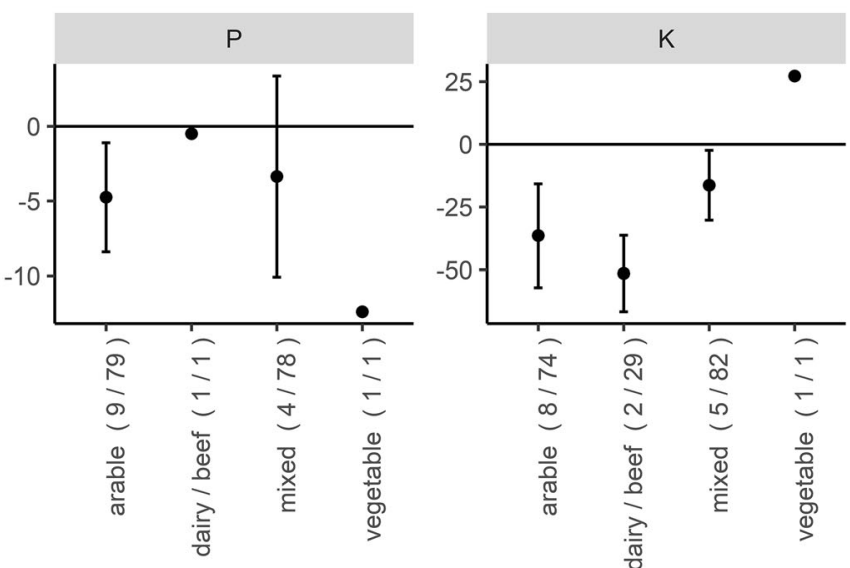

means derived from the meta-analysis in $\mathrm{kg} \mathrm{ha}^{-1}$ year $^{-1}$ and the bars the $95 \%$ confidence interval. The numbers behind the labels on the $\mathrm{x}$-axis show the number of studies and investigated farms

Difference between countries were observed for all nutrients (Fig. 2). A Belgian study by Padel et al. (2013) showed particularly high surpluses for N, P, and K. Also 
Table 2 Results of the moderator test of the meta-analysis of N, $\mathrm{P}$, and $\mathrm{K}$ budgets. Shown are the QM value and the $p$ value of the moderator omnibus test as well as the $R^{2}$ as a measure of the explained heterogeneity for the moderators "farm type," "budget method," and a "dummy variable" consisting of both farm type and budget method

\begin{tabular}{|c|c|c|c|c|c|c|}
\hline & \multicolumn{2}{|l|}{ Farm type } & \multicolumn{2}{|c|}{ Kind of balance } & \multicolumn{2}{|c|}{ Both (dummy variable) } \\
\hline & $p$ value & $R^{2}(\%)$ & $p$ value & $R^{2}(\%)$ & $p$ value & $R^{2}(\%)$ \\
\hline $\mathrm{N}$ & $<0.0001$ & 26 & 0.0072 & 11 & 0.0006 & 24 \\
\hline $\mathrm{P}$ & 0.0527 & 6 & 0.0051 & 17 & 0.0012 & 30 \\
\hline K & 0.0123 & 14 & 0.0191 & 10 & 0.0003 & 31 \\
\hline
\end{tabular}

the other countries investigated only by Padel et al. (2013), such as Finland or Romania, showed rather high budgets. Contrastingly, small budgets were observed in Sweden. However, the compositions of farm types investigated and budget method used differed significantly between countries. The investigated countries with number of country and farms for each farm type and budget method are shown in Supplementary Table 1.

\section{Discussion}

We observed a general imbalance in the nutrient supply of organic farms in Europe, where, as an average of the entire sector $\mathrm{N}, \mathrm{S}$, and $\mathrm{Mg}$ are supplied in excess of nutrient removal, the $\mathrm{P}$ budget is rather balanced due to high excesses in vegetable farms, and a removal of $\mathrm{K}$ in excess of resupply. In contrast to $\mathrm{N}$ and $\mathrm{S}$, the effects of budget surpluses or deficits on plant supply of $\mathrm{P}, \mathrm{K}$, and $\mathrm{Mg}$ are based on long-term soil processes; a deficit might not cause immediate yield depressions primarily (Løes and Øgaard 2001; Cooper et al. 2018). Yet, the resupply of depleted soil reserves is a challenge. In order to avoid long-term soil depletion, the calculation of nutrient budgets enables the early identification of these deficits, allowing the implementation of measures that prevent gradual soil nutrient depletion, which is particularly important for organic farms as an undetected deficit of $\mathrm{P}, \mathrm{K}$, or $\mathrm{S}$ may result in a decrease of BNF (Römer and Lehne 2004; Scherer 2008).

In addition, it must be noted that balanced nutrient budgets do not necessarily indicate that nutrient management strategies are successful. As both farm-gate and soil surface budgets are often based on simple input/ output calculations that disregard nutrient losses, these hidden deficits falsely shift nutrient balances towards the positive side. Especially $\mathrm{N}$ and $\mathrm{S}$ are prone to get lost from the system through, e.g., leaching or volatilization (Eriksen and Askegaard 2000; Berry et al. 2003). Therefore, certain surpluses in the amount of the unavoidable losses are needed to ensure adequate plant supply with $\mathrm{N}$ and $\mathrm{S}$. This means organic farming systems can still be regarded as $\mathrm{N}$ limited systems even if the input/ output budgets for $\mathrm{N}$ are positive.

The imbalances among the different nutrients arise either from the lack of use of fertilizers, but a high rate of leguminous crops in the crop rotation, meaning an input of $\mathrm{N}$, but no inputs of mineral nutrients like $\mathrm{P}$ and $\mathrm{K}$, or from the use of fertilizers that contain more than one nutrient but usually not in the same stoichiometry as the plant product offtakes. For example, solid manures or composts provide much more $\mathrm{P}$ in relation to the longterm offtakes by harvested products if they are applied in the needed amount of N (Möller and Schultheiß 2014). Therefore, the challenge for a suitable nutrient management system is to mix different fertilizers and BNF in a way that all nutrients are in a balanced inputoutput relation. In order to address these relations among nutrients, individual assessments for each farm are needed.

The represented means derived from the metaanalyses show the averages over all studies. The results of this study, however, highlight that in order to evaluate the nutrient budgets of organic farms, it is necessary to go into more detail since nutrient budgets differ depending on farm type, budgeting method, and country.

The number of studies reporting $\mathrm{N}, \mathrm{P}, \mathrm{K}, \mathrm{Mg}$, or $\mathrm{S}$ budgets also differed considerably. Research has been mainly focused on $\mathrm{N}$, as it is the plant nutrient with the quickest effect on plant growth and yield (Röös et al. 2018), while the effects of imbalances for example of $P$ and $\mathrm{K}$ can only be observed on a medium or long-term time span. Based on the current literature review, there is a need for more studies on $\mathrm{Mg}$ and especially $\mathrm{S}$. 


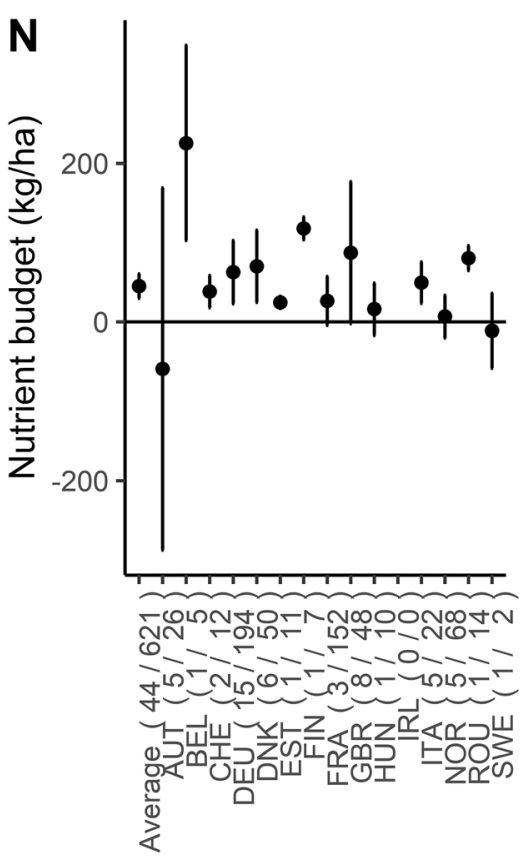

Fig. 2 Meta-analysis results of nutrient budgets of N, P, and $\mathrm{K}$ by country of origin. Dots represent the means derived from the metaanalysis in $\mathrm{kg} \mathrm{ha}^{-1}$ year ${ }^{-1}$ and the bars the $95 \%$ confidence

In our study, farm type was the most important moderator of the $\mathrm{N}$ budgets $\left(R^{2}=26 \%\right)$. Arable and mixed farms showed lower overall nutrient balances compared to dairy/beef farms or even vegetable farms. For $\mathrm{K}$ and especially for $\mathrm{P}$, farm type was of less importance in affecting heterogeneity of estimates $\left(R^{2}=16 \%\right.$ for $\mathrm{K}, R^{2}=6 \%$ for $\left.\mathrm{P}\right)$. In practice, farm type specific averages instead of the overall averages must be used for the evaluation of nutrient supply for the organic sector to avoid misinterpretation of the results. Vegetable farms, for instance, showed high surpluses of $\mathrm{P}$ but only represent a small fraction of the overall organic farmed area. In contrast, arable and mixed farms showed negative $\mathrm{P}$ budgets while constituting the major share of the total organic area. The average of these farms may therefore not be extrapolated to the organic farming sector as a whole. In sum, the findings for $\mathrm{N}$ and $\mathrm{P}$ are in line with a review by Watson et al. (2002b), while they differ slightly for $\mathrm{K}$. In contrast to our results, the authors found high $\mathrm{K}$ surpluses in vegetable and arable farms, small surpluses for dairy/beef farms, and slight deficits for mixed farms. However, their review focused more on dairy farms and showed only a small number of investigated arable, mixed, and vegetable farms. The difference among farm types can be explained by different nutrient management strategies.

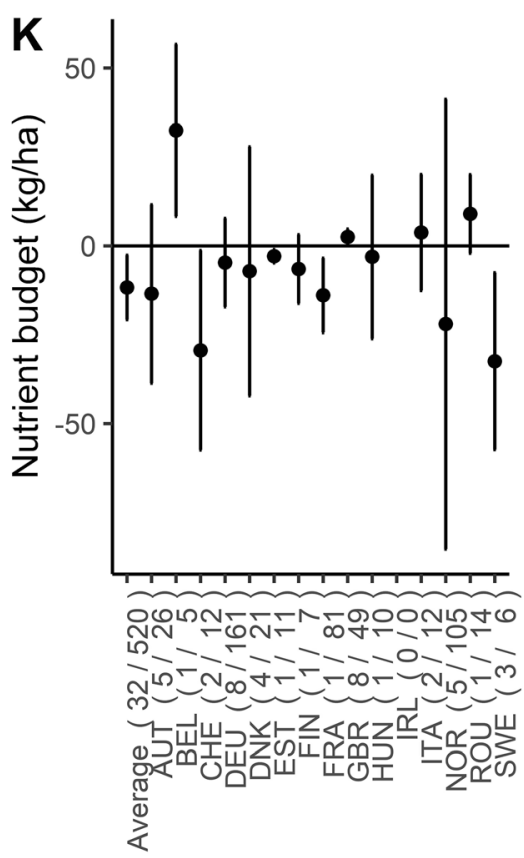

interval. The number behind the labels on the $\mathrm{x}$-axis shows the number of studies and investigated farms

In dairy farms, leys and forage legumes are a major tool for building soil fertility and adding $\mathrm{N}$ to the system through BNF. Further nutrient inputs derive from feed imports. Additionally, nutrients within farms can be recycled through animal manure production (Watson et al. 2002a). This use of animal manure, though, is always coupled with unavoidable losses, such as volatile $\mathrm{N}$ losses during storage and application (Taube and Pötsch 2001). These losses are not always included within $\mathrm{N}$ budgets as an output, therefore resulting in more positive budgets.

On arable farms, there is no possibility of nutrient recycling within the farm through manure and the amount of land devoted to leys and forage legumes is economically limited as no direct monetary return is achieved (Watson et al. 2002a). Therefore, soil fertility building is based on green manures, crop residue management, and grain legumes. Yet, these measurements usually do not fulfill the nutrient needs for other nutrients than $\mathrm{N}$, and additional nutrient inputs must come from external fertilizers, such as compost or manures, in order to replenish nutrient exports. The amount of $\mathrm{N}$ import into the farm and the type of fertilizer that are permitted to be used in organic farming systems are limited, which often results in their low availability on the market. Especially for P, adequate fertilizers besides 
compost and manures are missing. Farmers, therefore, cannot use the amount of fertilizers they need, which results in lower nutrient budgets.

Mixed farms represent a mixture between the two former mentioned systems, with the production of cash crops, as well as animal products. These farms have nutrient inputs via leys or forage legumes incorporated in the rotation, sometimes also via feed import. The manure produced by the farms animals is mainly used for the fertilization of the cash crops. Therefore, a nutrient shift from permanent grasslands to the arable lands can often be observed (Möller 2009a). This results in an overall lower nutrient budgets, especially on a farm level.

Soil fertility building in vegetable farms differs significantly from the former mentioned systems. Production costs for indoor greenhouse production are so high that a crop rotation with green manures or leys is not economically feasible. In open field vegetable production, the $\mathrm{N}$ demand of several crops, especially of the Brassica sp., is so high that $\mathrm{N}$ should be supplied also by external $\mathrm{N}$ fertilizers with a high short-term $\mathrm{N}$ release. Therefore, vegetable farms rely to a high extent on external nutrient imports, such as compost, animal manure, or commercial organic fertilizers (Watson et al. 2002a; Tittarelli et al. 2017; Zikeli et al. 2017; Möller 2018). In comparison with the average vegetable biomass, compost or solid animal manures provide related to plant offtakes and accounting also for long-term nutrient release two to three times more $\mathrm{P}$ per unit $\mathrm{N}$, which results in an $\mathrm{P}$ surplus, while $\mathrm{K}$ is often deficient (Zikeli et al. 2017).

Besides farm type, the method of nutrient budget calculation also moderated the magnitude of the nutrient budgets $\left(R^{2}=11 \%\right.$ for $\mathrm{N}, R^{2}=17 \%$ for $\mathrm{P}, R^{2}=10 \%$ for $\mathrm{K})$. Farm-gate budgets showed in general higher budgets than soil surface budgets. The literature review revealed no study comparing these different budget methods. Higher farm-gate budgets in comparison to soil surface budgets suggest that even if farms are better supplied with nutrients, crop requirements on the field might not be as high. Since farm-gate studies are often used by policy makers (Watson et al. 2002b), it is important to emphasize that a high farm-gate nutrient surplus does not necessarily imply a high nutrient surplus on the field. The difference in nutrients might be explained by unaccounted storage losses of fertilizers, especially for nutrients prone to volatile losses such as $\mathrm{N}$ or $\mathrm{S}$, and harvested products in the farm-gate budget calculation. In our study, the difference between soil surface studies and farm-gate studies might also lie in the composition of farm types for each budget method. Soil surface studies are usually carried out for arable farms, but not for dairy farms, which, as mentioned above, have higher budgets than arable farms. If the budgeting methods for each farm type are compared to each other, the difference among them was smaller. However, to allow a direct comparison, different methods of budget calculation need to be carried out for the same farm type.

The comparison among countries of origin for reported nutrient budgets should be interpreted with caution. The amount of research carried out in the reviewed countries differs significantly and the direct comparison might be biased due to different investigated farm types and budget methods. However, we observed some differences between countries (Fig. 2). Countries located in Central Europe such as Great Britain, Germany, and Denmark seemingly had higher budgets than more northern countries such as Sweden and Norway. A reason for these differences among countries could be farming intensity or availability of fertilizers permitted in organic farming. However, there is a clear need for a systematic study comparing nutrient budgets of organic farms throughout Europe simultaneously, using standardized method and distribution of farm types. The literature research only revealed two studies by Oelofse et al. (unpublished) on mixed and arable farms and Padel et al. (2013) on dairy farms, which compared differences among countries directly. Both studies cover seven different countries and compare budgets for $\mathrm{N}, \mathrm{P}$, and $\mathrm{K}$.

Besides the poor coverage of countries, the studies also revealed additional limitations. Direct comparison among studies was often complicated due to differences in included inputs, outputs, nutrient losses, or differences in calculation of BNF. In the present study, we tried to account for these differences by including a high number of studies, which would allow for an accurate estimation of average nutrient budgets. The nutrient budgets have further uncertainties due to the assumption of standard values for nutrient contents and mistakes in the farmers bookkeeping (Zikeli et al. 2017), as well as high degrees of uncertainties in the calculation of BNF. BNF is highly dependent on environmental factors such as soil moisture or soil $\mathrm{N}$ content, and yield level (Anglade et al. 2015), which are usually disregarded in the calculations for budget studies.

In order to determine the severity of nutrient surpluses or deficits and to allow recommendations for action to farmers or even policy makers, soil data on 
nutrient contents is needed (Watson et al. 2002b). If soil nutrient contents are high, a negative budget might even be desired to avoid negative effects on the environment. In contrast, if soil nutrient contents are already low, nutrient deficits should be minimized in order to avoid soil depletion of these nutrients. Slight nutrient surpluses are then desired to increase soil nutrient level back to the optimal range for plant production (Korsaeth 2012). This is especially true for $\mathrm{P}, \mathrm{K}$, and $\mathrm{Mg}$, since these nutrients are less mobile in the soil, which can therefore act as nutrient storage. Further, studies have shown that the soil content of plant available $\mathrm{P}$ and $\mathrm{K}$ is positively correlated with the budget (Reimer et al. under review; Løes and Øgaard 2001). Yet, only few studies include soil data. In the future, nutrient budget studies should aim to always incorporate soil data.

Finally, the topic of selection bias must also be addressed. Due to the language requirement, many studies had to be discarded. It seems that many nutrient budget studies are not always published in English, but rather in the language of the country of origin. This makes the studies more available to farmers within the country but not for international comparisons. Since the language requirement was extended to German, German speaking studies might be overrepresented in this study.

\section{Conclusion}

Nutrient budgets are a widespread tool in organic farming to investigate the nutrient supply of a farm. Most published studies in the presented meta-analysis investigate $\mathrm{N}$, $\mathrm{P}$, or $\mathrm{K}$, while studies concerning $\mathrm{Mg}$ and $\mathrm{S}$ are rare. On average, over all farm types and budgeting methods, we observed a meta-analytical surplus of $45 \mathrm{~kg} \mathrm{~N} \mathrm{ha}^{-1}$ year $^{-1}$, a balanced $\mathrm{P}$ budget of $0 \mathrm{~kg} \mathrm{P}^{-1}$ year $^{-1}$, and a deficit of $-12 \mathrm{~kg} \mathrm{~K} \mathrm{ha}^{-1}$ year $^{-1}$. Nutrient surpluses were also found for $\mathrm{Mg}\left(16 \mathrm{~kg} \mathrm{Mg} \mathrm{ha}{ }^{-1}\right.$ year $\left.^{-1}\right)$ and $\mathrm{S}$ (45 kg S ha ${ }^{-1}$ year $^{-1}$ ), although these should be interpreted with caution due to the low number of studies. However, the presented data does not provide an overall budget for the organic sector, as farms with deficits were underrepresented in the published literature, while specialty farms with high surpluses but a low area ratio (e.g., vegetable farms) were overrepresented. The type of farm represents an important factor, which should be considered when evaluating nutrient budgets of organic farms. In the current review, arable and mixed farms face more severe nutrient shortages than dairy/beef farms, while vegetable farms often have problems with nutrient surpluses. These imbalances between nutrients and farm types emphasize the challenge of nutrient management in organic farming by combining suitable fertilizers in a way that they match the composition of the farm's demand. Low availability of permitted fertilizers and the lack of adequate fertilizers, especially for $\mathrm{P}$, complicate the achievement of this goal even further. To develop suitable nutrient supply strategies for organic farms throughout Europe, the actual nutrient demand of organic farms must be assessed with regard to geographical location, budgeting method, and farm type. At the moment, there is a clear need for studies which compare nutrient budgets from different countries with the same budgeting method and simultaneously take different farm types into account.

Authors' contribution All authors contributed to the study conception and design. Material preparation, data collection, and analysis were performed by Marie Reimer. The first draft of the manuscript was written by Marie Reimer and all authors commented on previous versions of the manuscript. All authors read and approved the final manuscript.

Funding information Open Access funding provided by Projekt DEAL. This study was conducted within the RELACS project "Replacement of Contentious Inputs in Organic Farming Systems," which has received funding from the European Union's Horizon 2020 research and innovation program under grant agreement no. 773431. Tobias Edward Hartmann is funded by the Deutsche Forschungsgemeinschaft (DFG, German Research Foundation) - 328017493/GRK 2366 (International Research Training Group "Adaptation of maize-based food-feed-energy systems to limited phosphate resources").

Data availability The data set and the $\mathrm{R}$ script are available in the supplementary material.

\section{Compliance with ethical standards}

Conflict of interest The authors declare that they have no conflict of interest.

\section{References}

Andrist-Rangel Y, Edwards ACC, Hillier S, Öborn I (2007) Longterm $\mathrm{K}$ dynamics in organic and conventional mixed cropping systems as related to management and soil properties. Agric Ecosyst Environ 122:413-426. https://doi. org/10.1016/J.AGEE.2007.02.007 
Anglade J, Billen G, Garnier J, Makridis T, Puech T, Tittel C (2015) Nitrogen soil surface balance of organic vs conventional cash crop farming in the Seine watershed. Agric Syst 139:82-92

Asdal Á, Bakken AK (1999) Nutrient balances and yields during conversion to organic farming in two crop rotation systems. In: Olesen JE, Eltun R, Gooding MJ, Jensen ES, Kopke U (eds) Danish Research Centre for Organic Farming (DARCOF). Tjele, Denmark, pp 125-132

Askegaard M, Eriksen J (2000) Potassium retention and leaching in an organic crop rotation on loamy sand as affected by contrasting potassium budgets. Soil Use Manag 16:200-205

Bachinger J, Stein-Bachinger K (2000) Organic farming on large farms with special reference to eastern Germany. In: Wilson MJ, Maliszewska-Kordybach B (eds) Soil quality, sustainable agriculture and environmental security in Central and Eastern Europe. Springer Netherlands, Dordrecht, pp 125138

Bengtsson H, Öborn I, Jonsson S, Nilsson I, Andersson A (2003) Field balances of some mineral nutrients and trace elements in organic and conventional dairy farming - a case study at Öjebyn, Sweden. Eur J Agron 20:101-116. https://doi. org/10.1016/S1161-0301(03)00079-0

Berry PM, Sylvester-Bradley R, Philipps L, Hatch DJ, Cuttle SP, Rayns FW, Gosling P (2002) Is the productivity of organic farms restricted by the supply of available nitrogen? Soil Use Manag 18:248-255. https://doi.org/10.1111/j.14752743.2002.tb00266.x

Berry PM, Stockdale EA, Sylvester-Bradley R, Philipps L, Smith KA, Lord EII, Watson CAA, Fortune S (2003) N, P and K budgets for crop rotations on nine organic farms in the UK. Soil Use Manag 19:112-118. https://doi.org/10.1079 /SUM2003176

Blicher-Mathiesen G, Andersen HE, Larsen SE (2014) Nitrogen field balances and suction cup-measured $\mathrm{N}$ leaching in Danish catchments. Agric Ecosyst Environ 196:69-75

Boldrini A, Benincasa P, Tosti G, Tei F, Guiducci M (2007) Apparent $\mathrm{N}$ balance in organic and conventional low input cropping systems. In: Niggli U, Leifert C, Alföldi T, Lück L, Willer H (eds) 3rd QLIF Congress. Research Institute of Organic Agriculture (FiBL), Hohenheim, Germany, pp 264-267

Cooper J, Reed EY, Hörtenhuber S, Lindenthal T, Løes A-K, Mäder P, Magid J, Oberson A, Kolbe H, Möller K (2018) Phosphorus availability on many organically managed farms in Europe. Nutr Cycl Agroecosystems 110:227-239. https://doi.org/10.1007/s10705-017-9894-2

Cuttle SP (2002) Nutrient budgets as a tool for researchers and farmers. UK Org Res:169-172

Erhart E, Forster A, Hartl W (2002) Agriculture in Viennanutrient balances. In: Magid J, Lieblein G, Granstedt A, Kahiluoto H, Dýrmundsson Ó (eds) Danish Research Centre for Organic Farming (DARCOF), Tjele, Denmark, pp 157-165

Eriksen J, Askegaard M (2000) Sulphate leaching in an organic crop rotation on sandy soil in Denmark. Agric Ecosyst Environ 78:107-114. https://doi.org/10.1016/S0167-8809 (99)00117-6

Fliessbach A, Mäder P, Dubois D, Gunst L (2000) Results from a 21 year old field trial. Organic farming enhances soil fertility and biodiversity. FiBL Doss $15 \mathrm{pp}$
Foissy D, Vian JF, David C (2013) Managing nutrient in organic farming system: reliance on livestock production for nutrient management of arable farmland. Org Agric 3:183-199

Fortune S, Stockdale EA, Philipps L, Conway JS, Robinson JS, Watson CA (1999) Optimising phosphorus and potassium management for crop rotations in UK organic farming systems. In: Olesen JE, Eltun R, Gooding MJ, Jensen ES, Kopke U (eds) Danish Research Centre for Organic Farming (DARCOF), Tjele, Denmark, pp 267-275

Fowler SM, Watson CA, Wilman D (1993) N, P and K on organic farms: herbage and cereal production, purchases and sales. $\mathrm{J}$ Agric Sci 120:353-360. https://doi.org/10.1017 /S0021859600076516

Giustini L, Argenti G, Acciaioli A (2008) Apparent balance of nitrogen in organic and conventional dairy farms in Tuscany (Central Italy). In: Hopkins A, Gustafsson T, Bertilsson J, Dalin G, Nilsdotter-Linde N, Spörndly E (eds) Swedish University of Agricultural Sciences, Uppsala, Sweden, pp 583-585

Goulding K, Stockdale E, Fortune S, Watson C (2000) Nutrient cycling on organic farms. In: J. R. Agric. Soc. Engl. https://orgprints.org/8053/. Accessed 24 Mar 2020

Goulding K, Stockdale E, Watson C (2008) Plant nutrients in organic farming. In: Organic crop production-ambitions and limitations. Springer, pp 73-88

Gruber L, Steinwender R, Guggenberger T, Plakolm G (2001) Comparison of organic and conventional farming on a grassland farm. 3rd Communication: nutrient balances on supply/ withdrawal basis and import/export basis. Bodenkultur 52: 183-195

Gutser R, Reents HJ, Rühling I, Schmid H, Weinfurtner KH (2002) Forschungsverband Agrarökosysteme München Langzeitmonitoring und Indikatoren 13

Haas G, Deittert C, Köpke U (2007) Farm-gate nutrient balance assessment of organic dairy farms at different intensity levels in Germany. Renew Agric Food Syst 22:223-232. https://doi.org/10.1017/S1742170507001780

Halberg N, Steen Kristensen E, Sillebak Kristensen I (1995) Nitrogen turnover on organic and conventional mixed farms. J Agric Environ Ethics 8:30-51. https://doi.org/10.1007 /BF02286400

Hansen B, Kristensen ES, Grant R, Høgh-Jensen H, Simmelsgaard SE, Olesen JE (2000) Nitrogen leaching from conventional versus organic farming systems - a systems modelling approach. Eur J Agron 13:65-82

Haraldsen TK, Asdal Á, Grasdalen C, Nesheim L, Ugland TN (1999) Nutrient balances and yields during conversion from conventional to organic cropping systems on silt loam and clay soils in Norway. Biol Agric Hortic 17:229-246

Hartl W, Erhart E (2002) Improving the nutrient balance of Vienna's agriculture through compost use - a scenario. In: Magid J, Lieblein G, Granstedt A, Kahiluoto H, Dýrmundsson Ó (eds) Danish Research Centre for Organic Farming (DARCOF), Tjele, Denmark, pp 167-174

Hege U, Fischer A, Offenberger K (2003) Nährstoffsalden und Nitratgehalte des Sickerwassers in ökologisch und üblich bewirtschafteten Ackerflächen. Inst Für Agrar Ökol Landbau Bodenschutz Hrsg Tagungsband Forsch Für Den Ökol Landbau Bayern Bayer Landesanst Für Landwirtsch LfL Freis Schriftenreihe Bayer Landesanst Für Landwirts:714 
HungChun L, Huber JA, Gerl G, Hülsbergen KJ (2016) Nitrogen balances and nitrogen-use efficiency of different organic and conventional farming systems. Nutr Cycl Agroecosystems 105:1-23

IFOAM (2017) The IFOAM standard for organic production and processing. In: The IFOAM Norms for Organic Production and Processing. IFOAM-Organics International, pp 25-66

Klem M, Hüwing H, Kemper N (2007) COMPASS Vergleichende Analyse der pflanzlichen Produktion auf ökologischen und konventionellen Praxisbetrieben in Schleswig-Holstein. Christian-Albrechts-Universität, Kiel

Korsaeth A $(2012$, 2012) N, P, and K budgets and changes in selected topsoil nutrients over 10 years in a long-term experiment with conventional and organic crop rotations. Appl Environ Soil Sci:Article ID 539582

Korsaeth A, Eltun R (2000) Nitrogen mass balances in conventional, integrated and ecological cropping systems and the relationship between balance calculations and nitrogen runoff in an 8-year field experiment in Norway. Agric Ecosyst Environ 79:199-214

Küstermann B, Christen O, Hülsbergen K-J (2010) Modelling nitrogen cycles of farming systems as basis of site- and farm-specific nitrogen management. Agric Ecosyst Environ 135:70-80. https://doi.org/10.1016/J.AGEE.2009.08.014

Løes AK, Øgaard AF (1997) Changes in the nutrient content of agricultural soil on conversion to organic farming in relation to farm-level nutrient balances and soil contents of clay and organic matter. Acta Agric Scand Sect B - Soil Plant Sci 47: 201-214. https://doi.org/10.1080/09064719709362462

Løes AK, Øgaard AF (2001) Long-term changes in extractable soil phosphorus (P) in organic dairy farming systems. Plant Soil 237:321-332

Loges R, Kelm MR, Taube F (2006) Nitrogen balances, nitrate leaching and energy efficiency of conventional and organic farming systems on fertile soils in Northern Germany. Adv Geoecology:407-414

Migliorini P, Moschini V, Tittarelli F, Ciaccia C, Benedettelli S, Vazzana C, Canali S (2014) Agronomic performance, carbon storage and nitrogen utilisation of long-term organic and conventional stockless arable systems in Mediterranean area. Eur J Agron 52:138-145

Möller K (2009a) Inner farm nutrient flows between arable land and permanent grassland via the stable in organic cropping systems. Eur J Agron 31:204-212. https://doi.org/10.1016/j. eja.2009.07.007

Möller K (2009b) Influence of different manuring systems with and without biogas digestion on soil organic matter and nitrogen inputs, flows and budgets in organic cropping systems. Nutr Cycl Agroecosystems 84:179-202. https://doi. org/10.1007/s10705-008-9236-5

Möller K (2018) Soil fertility status and nutrient input-output flows of specialised organic cropping systems: a review. Nutr Cycl Agroecosystems 112:147-164. https://doi. org/10.1007/s10705-018-9946-2

Möller K, Schultheiß U (2014) Organische Handelsdüngemittel im ökologischen Landbau. Kuratorium für Technik und Bauwesen in der Landwirtschaft e.V. (KTBL), Darmstadt, Germany

Morari F, Lugato E, Polese R, Berti A, Giardini L (2012) Nitrate concentrations in groundwater under contrasting agricultural management practices in the low plains of Italy. Agric Ecosyst Environ 147:47-56

Nesme T, Toublant M, Mollier A, Morel C, Pellerin S (2012) Assessing phosphorus management among organic farming systems: a farm input, output and budget analysis in southwestern France. Nutr Cycl Agroecosystems 92:225-236. https://doi.org/10.1007/s10705-012-9486-0

Nielsen AH, Kristensen IS (2005) Nitrogen and phosphorus surpluses on Danish dairy and pig farms in relation to farm characteristics. Livest Prod Sci 96:97-107. https://doi. org/10.1016/j.livprodsci.2005.05.012

Nolte C, Werner W (1994) Investigations on the nutrient cycle and its components of a biodynamically-managed farm. Biol Agric Hortic 10:235-254. https://doi.org/10.1080 /01448765.1994.9754676

Nowak B, Nesme T, David C, Pellerin S (2013) Disentangling the drivers of fertilising material inflows in organic farming. Nutr Cycl Agroecosystems 96:79-91. https://doi.org/10.1007 /s10705-013-9578-5

Oehl F, Oberson A, Tagmann HU, Besson JM, Dubois D, Mäder P, Roth HR, Frossard E (2002) Phosphorus budget and phosphorus availability in soils under organic and conventional farming. Nutr Cycl Agroecosystems 62:25-35

Oelofse M, Jensen LS, Magid J (2013) The implications of phasing out conventional nutrient supply in organic agriculture: Denmark as a case. Org Agric 3:41-55. https://doi. org/10.1007/s13165-013-0045-z

Oelofse M, Reimer M, Müller-Stöver D, Möller K, Bünemann EK, Bianchi S, Vetemaa A, Drexler D, Trugly B, Blogg H, Rasmussen A, Verrastro V, Magid J (unpublished) An assessment of external nutrient input use on organic farms: case study evidence from seven European countries

Øgaard AF, Hansen S (2010) Potassium uptake and requirement in organic grassland farming. Nutr Cycl Agroecosystems 87: 137-149

Ohm M, Paulsen HM, Moos JH, Eichler-Löbermann B (2017) Long-term negative phosphorus budgets in organic crop rotations deplete plant-available phosphorus from soil. Agron Sustain Dev 37:17

Padel S, Gerrard CL, Leach K, Smith LG, Topp CFE, Watson C (2013) The devil is in the detail: finding meaningful indicators of nutrient management on organic and low-input farms. Asp Appl Biol:83-88

R Core Team (2018) R: a language and environment for statistical computing. R Foundation for Statistical Computing, Vienna, Austria

Reimer M, Hartmann TE, Oelofse M, Magid J, Bünemann EK, Möller K (under review) Farm gate nutrient budgets in organic farms - a case study in Germany. Nutr Cycl Agroecosystems

Römer W, Lehne P (2004) Vernachlässigte Phosphor- und Kaliumdüngung im ökologischen Landbau senkt die biologische Stickstofffixierung bei Rotklee und den Kornertrag bei nachfolgendem Hafer. J Plant Nutr Soil Sci 167:106-113. https://doi.org/10.1002/jpln.200320337

Röös E, Mie A, Wivstad M, Salomon E, Johansson B, Gunnarsson S, Wallenbeck A, Hoffmann R, Nilsson U, Sundberg C, Watson CA (2018) Risks and opportunities of increasing yields in organic farming. A review. Agron Sustain Dev 38: 14. https://doi.org/10.1007/s13593-018-0489-3 
Ruane EM, Treacy M, Lalor S, Watson CJ, Humphreys J (2013) Farm-gate phosphorus balances and soil phosphorus concentrations on intensive dairy farms in the south-west of Ireland. In: Helgadóttir Á, Hopkins A (eds). Agricultural University of Iceland, Borgarnes, Iceland, pp 141-143

Scherer HW (2008) Impact of sulfur on N2 fixation of legumes. In: Khan NA, Singh S, Umar S (eds) Sulfur assimilation and abiotic stress in plants. Springer, Berlin, Heidelberg, pp 4354

Schmidtke K, Wunderlich B, Lauter J, Wendrock Y, Kolbe H (in press) Nährstoff- und Humusbilanz sowie Nährstoffversorgung im Boden von langjährig ökologisch bewirtschafteten Ackerund Grünlandflächen im Freistaat Sachsen

Starz W, Steinwidder A, Zollitsch W, Jandl S, Pfister R, Rohrer H (2013) Nutrient balances of organic dairy farms in permanent grassland area with reduced concentrate feeding. Lehr- und Forschungszentrum für Landwirtschaft RaumbergGumpenstein, Irdning, Austria, pp 111-114

Steinshamn H, Thuen E, Bleken MA, Brenøe UT, Ekerholt G, Yri $\mathrm{C}$ (2004) Utilization of nitrogen $(\mathrm{N})$ and phosphorus $(\mathrm{P})$ in an organic dairy farming system in Norway. Agric Ecosyst Environ 104:509-522

Tagmann HU, Oberson A, Oehl F, Frossard E, Dubois D, Mäder P (2001) DOC-trial: phosphorus budget and availability over 21 years. Agrarforschung 8:318-323

Taube F, Pötsch EM (2001) On-farm nutrient balance assessment to improve nutrient management on organic dairy farms. Grassl Sci Eur

Taube F, Wachendorf M, Greef JM, Wulfes R (1997) Perspektiven semi-intensiver Produktionssysteme in Milchvieh-/Futterbauregionen Norddeutschlands. Berichte Uber Landwirtsch 75:586-603

Thorup-Kristensen K, Dresbøll DB, Kristensen HL (2012) Crop yield, root growth, and nutrient dynamics in a conventional and three organic cropping systems with different levels of external inputs and $\mathrm{N}$ re-cycling through fertility building crops. Eur J Agron 37:66-82

Tittarelli F, B \a ath B, Ceglie FG, García MC, Möller K, Reents HJ, Védie H, Voogt W (2017) Soil fertility management in organic greenhouse: an analysis of the European context. Acta Hortic:113-126. https://doi.org/10.17660 /ActaHortic.2017.1164.15
Torstensson G, Aronsson H, Bergström L (2006) Nutrient use efficiencies and leaching of organic and conventional cropping systems in Sweden. Agron J 98:603-615. https://doi.org/10.2134/agronj2005.0224

Viechtbauer W (2010) Conducting meta-analyses in R with the metafor package. J Stat Softw 36:1-48. https://doi. org/10.1103/PhysRevB.91.121108

Walter SD, Yao X (2007) Effect sizes can be calculated for studies reporting ranges for outcome variables in systematic reviews. J Clin Epidemiol 60:849-852. https://doi.org/10.1016/j. jclinepi.2006.11.003

Watson CA, Atkinson D (1999) Using nitrogen budgets to indicate nitrogen use efficiency and losses from whole farm systems: a comparison of three methodological approaches. Nutr Cycl Agroecosyst 53:259-267. https://doi.org/10.1023 /A:1009793120577

Watson CA, Atkinson D, Gosling P, Jackson LR, Rayns FW (2002a) Managing soil fertility in organic farming systems. Soil Use Manag 18:239-247. https://doi.org/10.1111/j.14752743.2002.tb00265.x

Watson CA, Bengtsson H, Ebbesvik M, Løes A-K, Myrbeck A, Salomon E, Schroder J, Stockdale EA (2002b) A review of farm-scale nutrient budgets for organic farms as a tool for management of soil fertility. Soil Use Manag 18:264-273. https://doi.org/10.1079/SUM2002127

Weir CJ, Butcher I, Assi V, Lewis SC, Murray GD, Langhorne P, Brady MC (2018) Dealing with missing standard deviation and mean values in meta-analysis of continuous outcomes: a systematic review. BMC Med Res Methodol 18:1-14. https://doi.org/10.1186/s12874-018-0483-0

Wieser I, Hess J, Lindenthal T (1996) Nitrogen-, phosphorus-, and potassium-balances on organically managed grassland farms in the Upper Austrian Alpine foreland. Bodenkultur 47:8188

Zikeli S, Deil L, Möller K (2017) The challenge of imbalanced nutrient flows in organic farming systems: a study of organic greenhouses in Southern Germany. Agric Ecosyst Environ 244:1-13. https://doi.org/10.1016/j.agee.2017.04.017

Publisher's note Springer Nature remains neutral with regard to jurisdictional claims in published maps and institutional affiliations. 